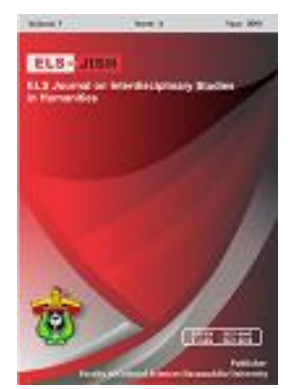

ELS-JISH

ELS Journal on Interdisciplinary Studies on Humanities

Volume 2 Issue 3, 2019

ISSN (print) : 2621-0843

ISSN (online) : 2621-0835

Homepage : http://journal.unhas.ac.id/index.php/jish

\title{
The English Pragmatic Competence of Indonesian English Speakers
}

\author{
Ermansyah Malik ${ }^{1}$ \\ 1 ermansyah.malik@unifa.ac.id
}

\begin{abstract}
The aim of the research were (1) to examine participants' pragmatics competence toward English formal, neutral and formal request, (2) to find evidence of the participants' lack of pragmatics competence toward various setting of English pragmatics situations.qualitative and quantitative methods were applied to analyze the result of the findings. English grammar competence test was given to determine the subjects' grammar competence. The English pragmatic test was given to determine the subject' competence on English pragmatic.the subjects of the research were grouped into 3 categories; group a, subjects whose English grammar competence are at basic level, group b, subjects whose English grammar competence are at intermediate level and group c, subjects whose English grammar competence are at advance level. Each group consists of 5 individuals, who have no prior information of the test model and the aims of the research. lelts model test is administered before the pragmatic competence test, to groups the subjects of the research. There are 3 parts of the English pragmatic competence which researcher applied to determine the result of the research, (1) identifying formal, informal and neutral request utterances, (2) expressing willingness and unwillingness with reasons in using the utterances (3) answering appropriately to multiple questions.the result of the research shows different finding from each of the English grammar competence level. The research result unsurprisingly shows low level of pragmatics competence at intermediate and basic level of grammar competence. Different result showed at higher level whereas the relationship between grammar and pragmatic competence is strong.
\end{abstract}

Keywords: Pragmatic, English Grammar Competence, IELTS

How to cite: Ermansyah. (2019). The English Pragmatic Competence of Indonesian English Speakers. ELS Journal on Interdisciplinary Studies in Humanities, 2 (3), 477-484

\section{Introduction}

Indonesian education system of English pedagogic has put the linguistic knowledge componentsas the base of all curricula at almost all levels of teaching. The four skills of reading, writing, listening and speaking competence are designed for learners to recognise and operate the language communicatively among them, thus first language pragmatic may either interfere or absorb in the second language communication interface. The exclusion of the second language pragmatic knowledge in Indonesian English education system will surely prone to communication breakdown at international level of communication. 
Pragmatics is a subfield of linguistics that has been defined as the study of language from the point of view of users, especially of the choices they make, the constraints they encounter in using the language in social interaction and the effects their use of language has on other participants in the act of communication'. (Crystal, 1997, p.301). The terminology of Pragmatics competence was originally placed within the philosophy of language (Morris, 1983), but then has developed in use at other sub-disciplines such as sociolinguistics. The term then has excessively used in the field of second and foreign language pedagogic. As Chomsky (1980 p.224) described, "knowledge of condition and manner of appropriate use (of the language) in conformity with various purposes". This concept as the opposition to "grammatical competence', which is the "knowledge of form and meaning'

Pragmatics has long been considered one of the acquired competences which English learners find challenging to master. This competence is neither learnt nor taught in classroom mode, thus it is impossible without prior experience of language interaction in its real environment. One mother tongue pragmatic competence might too different or difficult than second language pragmatic. In this respect, Blum-Kulka (1991) states, the main obstacle to learners' exploiting their general knowledge base appears to be their restrictedsecond language linguistic knowledge or difficulty in accessing it smoothly. Furthermore, to acquiring processing control over their already existing pragmatic foundations, adult second language or foreign language learners need to develop new representation of pragmalinguistic and sociopragmatic knowledge not existing in their L1 (Byalistoc, 1993). Thus, Nemser (1971) adds, learner language is not a deviant system represented by language learners at "successive stages of proficiency", or one typical of nonnative speakers "communicating imperfectly in English".

Pragmatics competence is defined as 'knowledge of how an addressee determines what a speaker is saying and recognizes intended illocutionary force conveyed through subtle attitudes in the speaker's utterance' (Fraser, 1983, P.29). Understanding of the features of pragmatics of the target language is important as the understanding of the features of the grammar to ensure the development of the communication competence of the language learners. As a result, features of pragmatics of the target language should be incorporated into foreign language classes (Rafieyan 2016a; Rafieyan, 2016b; Rafieyan, 2016c). The claim of the importance of the pragmatics competence is supported by Bachman's (1990) model communicative competence which considers pragmatic competence and grammatical competence as two distinct aspect of communicative competence. Research has revealed that the level of grammatical knowledge does not necessarily mean a high pragmatics knowledge, and even the advance levels of language proficiency learners may not and possibly cannot achieve a native-like pragmatics competence (Bardovi-Harlg \& Dornyei, 1998; Bardovi-Harlig, 2001; Barron, 2003; Gharaghani et. Al., 2011)

Bordovi-Harlig et al. (2008), have investigated and questioned the pragmatics competence of language learners. They examined the impact of the level of instruction and the use of first language on the development and use of specific pragmatics aspects of competence, referred to as conventional expressions. The findings of this research showed that language learners of various native languages often share strategies of production and language learners develop their 
conventional expressions usage at the higher levels of competence. The research findings also signal that exposure to target language in the target language environment can be a contributing factor to the development of competence in pragmatics.

\section{Methodology}

In this research of pragmatics competence the researcher intends to provide proofs of the Indonesian perception of politeness in the area of requests. Are Indonesian learners of English sensitive enough to distinguish how the Politeness Principle (Lakoff, 1995) operates differently in the Bahasa Indonesia and English environment? Are they able to recognize the rules of a polite conversation at all?

Indonesians tend to be more indirect than the English people. This indirectness is often apparent as a result of a negative transfer from Bahasa Indonesia in general. What an Indonesian learner of English regards as polite, a native speaker may view to have quite an opposite impact, being inappropriate and causing social disharmony.

All the participants in this research were adult and were grouped into 3 level of grammar competencies (based on their earlier-administered IELTS test) and were supposed to be at the level of appropriate grammar competence of English since they are in post graduate program of English with a university degree in English. Sex or age of the participants was not taken into consideration. No particular pragmatic instructions had been given to them before the test. It is difficult to say to what extent they had come across pragmatic training, since they had been taught by several teachers each of whom would have their own preferences in teaching methods and priorities. They had also been exposed to a number of course books.

The aim of this research was to test subjects' pragmatic competence and find evidence of the lack (failures to identify) of subjects' English pragmatics competence toward various scope of pragmatics parameters, namely formal, neutral and informal request. The test conducted on subjects who are being considered intermediate to advance English users, based on their level of proficiency, should already have developed to some extent.

According to the common European referential framework, learners of English at intermediate level (B1) are expected to be able to understand the main points of clear standard input on familiar matters regularly encountered in work, school, leisure, etc. They should be able to deal with most situations likely to arise while travelling in an area where the language is spoken. They should manage to produce simple connected text on topics which are familiar or of personal interest. They can describe experiences and events, dreams, hopes and ambitions and briefly give reasons and explanations for opinions and plans.

\section{Findings}

\subsection{Formal, neutral and informal expressions.} requests:

In the first part of the research, participants were provided with a number of 
a. l'd be grateful if you could...

b. Could you...

c. I wonder if you could...

d. Is it alright if we...

e. I wonder if it might be possible to...

f. Please could you...

g. Do you mind...

h. Would you mind...

i. Can I have...

j. Do you think I could...

k. Could you possibly...

I. Thank you in advance for your help in this matter...

m. l'd appreciate your help on this.

n. Would you...

The subjects of the research were supposed to mark the each phrases $F$ (formal), I (informal), N (neutral) based on their prior knowledge and understanding of the expression or phrases. The participants' perception of different formality levels of the requesting phrases is shown in table 1. Neither the successful identification of the phrases nor performance of particular participants is commented on as these were not the objectives of the research.

Table 1. Participants' marking of formal (F), informal $(\mathrm{I})$ and neutral $(\mathrm{N})$ phrases.

\begin{tabular}{|c|c|c|c|c|c|c|c|c|c|c|c|c|c|c|}
\hline$\%$ & $\mathrm{a}$ & $b$ & $C$ & $d$ & e & $f$ & $g$ & $\mathrm{~h}$ & $\mathrm{i}$ & $\mathrm{j}$ & $\mathrm{k}$ & 1 & $\mathrm{~m}$ & $n$ \\
\hline $\mathrm{F}$ & $\begin{array}{r}87 \\
.5\end{array}$ & $\begin{array}{c}37 . \\
5\end{array}$ & $\begin{array}{c}87 . \\
5\end{array}$ & 25 & $\begin{array}{c}10 \\
0\end{array}$ & $\begin{array}{c}37 . \\
5\end{array}$ & $\begin{array}{l}2 \\
5\end{array}$ & 75 & $\begin{array}{c}12 . \\
5\end{array}$ & 50 & 75 & $\begin{array}{c}87 . \\
5\end{array}$ & 50 & 50 \\
\hline I & $\begin{array}{c}12 \\
.5\end{array}$ & 25 & - & 25 & - & $\begin{array}{c}12 . \\
5\end{array}$ & $\begin{array}{l}2 \\
5\end{array}$ & 12.5 & 25 & $\begin{array}{c}12 . \\
5\end{array}$ & $\begin{array}{c}12 . \\
5\end{array}$ & - & & 25 \\
\hline $\mathrm{N}$ & - & $\begin{array}{c}37 . \\
5\end{array}$ & $\begin{array}{c}12 . \\
5\end{array}$ & 50 & - & 50 & $\begin{array}{l}5 \\
0\end{array}$ & 12.5 & $\begin{array}{c}62 . \\
5\end{array}$ & $\begin{array}{c}37 . \\
5\end{array}$ & $\begin{array}{c}12 . \\
5\end{array}$ & $\begin{array}{c}12 . \\
5\end{array}$ & 50 & 25 \\
\hline
\end{tabular}

There was substantial variation across the participants. The participants were not particularly consistent in their perception of different formality levels. Despite the low number of participants 8 (eight), the research reflects a rather low pragmatic ability of students. The results demonstrate the findings that a relatively high level of proficiency does not guarantee a high level of pragmatic competence.

\subsection{Usage of pragmatics expressions}

In the second part of my pragmatic research, students were to decide which of the phrases they would never use in a conversation and, on the contrary, which do they use most often.

Question 1: Which of the phrases would you personally never use? Why not? 
Students' comments are as follows:

S1: I would never use phrases a, c, e, $\mathbf{k}, \mathbf{I}, \mathbf{m},-$ I never use that because it is formal sentences, usually we use that for old people or teacher, but I never talk with old people use English language.

S2: I would never use phrasesa, c, e, h, j, I, m, - because I only like the simple phrases besides, it is easier than the others

S3: I would never use phrasesi,-- it is too long. It takes time to say it

S4: I would never use phrasesa, $\mathbf{c}, \mathbf{e}, \mathbf{k}, \mathbf{l}$, - those phrases are to formal formal for me

S5: I would never use phrasesa, e, I, $\mathbf{m}$ - those expression seems too much formal while it rare to use English in formal situation

S6: I would never use phrasesa, - I don't use formal language too often.

S7: I would never use phrasesl, - it's too long

S8: I would never use phrasesl, - because it's too long

There was a unifying tendency not to select the long phrases for being complicated and too polite. Some participants were not able to identify any phrases they would not probably be willing to use.

Question 2: Which ones do you use the most often?

Students' choice:

7 students chose b. $(87.5 \%)$,

5 students chose i. $(62.5 \%)$

4 students chose n. $(50 \%)$

3 students chose g. $(37.5 \%)$

2 students chose f. (25\%)

2 students chose h. $(25 \%)$

1 student chose j. (12.5\%)

Students follow their strong inclination to use short phrases with modals can and could, which they probably learnt at the beginning of their studies. This might have not been in the context of requests but as means of expressing ability.

\subsection{Appropriateness of pragmatics expressions.}

The third part of the research was conducted in the form of a multiple choice test. Participants were supposed to read five requests and choose a response which is not appropriate. No grammatical errors were included. Students were to recognize errors related to an inappropriate formality or politeness level and some typical errors caused by a negative transfer from Bahasa Indonesia were also included.

1. Do you mind opening the door for me?
a. Not at all.
b. OK.
c. Yes, of course. 
2. May I come in?
a. Of course.
b. Please, do.
c. You are welcome.

3. Can you switch off the TV? (mother to her son)

a. Yes, of course. b. Sorry, but... c. I'm sorry. That's not possible.

4. Could I borrow your dictionary? (two classmates)

a. OK. Here it is. $\quad$ b. Yes, sure. c. By all means.

5. Would you be kind enough to let me know?
a. Yeah, sure.
b. Yes, certainly.
C. l'd be glad to.

Negative transfer was apparent in request 1 and $2.50 \%$ of participants identified option c (Yes, of course) as an inappropriate response to Do you mind opening the door for me? And $50 \%$ of participants considered the phrase You are welcome as not appropriate in request 2. Requests 3, 4 and 5 were much better evaluated. Only $37.5 \%$ of participants chose the correct option in requests 3 and there are $50 \%$ in request 4 , and $62.5 \%$ as for request 5 .

\section{Conclusion}

The results of this sub-test show that the participantsin general (since some participants failed to read the instructions) were relatively capable of identifying the inappropriate level of formality and politeness. On the other hand, they were rather misled by the temptation to rely on the rules of Indonesian social responses.

The research proved that the participants' pragmatic knowledge on the formal, neutral and informal was inconsistent; it showed that the participants built some kind of doubt in selecting the utterance as formal, neutral or informal. The inconsistent identification is treated as the inability to identify the obvious pragmatics knowledge of the native speakers.

The research also proved that most participants selected the monotonous simple can and couldin building their communication mode of requesting, this of course showed the lack of knowledge of using wider selection of modal for request. Therefore, the research found evidence of participants' requesting strategies is not very profound.

The participants' pragmatics knowledge may largely be influenced by their early language learning experience, where English is shaped by traditional linguistic competency based curriculum. The participants would obviously benefit from the teachers' pragmatic instruction if it was given on a real English environment and at regular basis. Another factor has to be taken into consideration, is the students' motivation. Learners often use English primarily as a means of communication. Their ambition is to become capable of making complete sentences without inspecting their pragmatic functions. In English as a Foreign Language environment the motivation to 
understand the social meaning of utterances has never been the main or even the second target of English learners competence.

\section{Suggestion}

Since the research has shown the different levels of understanding of the English Grammar and English Pragmatics, and that the evidence suggests that the relationship is strong at the higher level of grammar competence to English grammar competence. The researcher proposes some approaches that may be best applied during the teaching and learning process of both English grammar and English competence, they are; first, the teaching and learning of English grammar should always include the understanding of English contextual, which aim to strengthen students' understanding of pragmatics usage in communication. Secondly, there must be topic related for every exercise of language teaching and learning which derive students to identify the usage of formal, informal and neutral usage of English expressions in context learning. Thirdly, it is recommended that the students of English should always keep in mind that learning a language means learning and absorbing cultural aspect of a language, grammar is never be the only insurance to successful communication, pragmatics understanding is also one of the key to successful and much natural way of learning a language, in this matter, English.

\section{References}

Bachman, L. F. (1990) Fundamental considerations in language testing. Oxford University Press

Bardovi-Harlig, K. (2009) Conventional expressions as a pragma linguistic resource: Recognition and production of conventional expression in L2 pragmatics. Language Learning, 59(4), 755-795. http://doi.org/10.1111/j.14679922.2009.00525.x

Bardovi-Harlig, K. (1999). Exploring the interlanguage of interlanguage pragmatics: A research agenda for acquisitional pragmatics. Language learning, 49, 677-713.

Bardovi-Harlig, K. (2001). Evaluating the empirical evidence: Grounds for instruction in pragmatics. In Kasper, G., \& Rose, K. (Eds.). Pragmatics and language teaching, (pp.11-32).Cambridge: Cambridge University Press.

Bardovi-Harlig, K., \& Hartford, B. (1990) Congruence in native and nonnative conversations: Status balance in the academic advising session. Language learning, 40, 467-501.

Bardovi-Harlig, K., \& Hartford, B. (1991). Saying "No": Native and nonnative rejections in English. In L. F. Bouton\& Y. Kachru (Eds.) Pragmatics and Language Learning, (Vol.2, pp.41-57). University of Illinois, Urbana-Champaign: Division of English as an International Language.

Bardovi-Harlig, K., \& Hartford, B. (1996). Input in an institutional setting. Studies in Second

Language Acquisition, 15, 279-304. 
Bialystok, E. (1993). Symbolic representation and attentional control in pragmaticcompetence. In Kasper, G., \& Blum-Kulka, S. (Eds.) Interlanguage Pragmatics (pp. 43-57).Oxford: Oxford University Press.

Blum-Kulka, S. (1991). Interlanguage Pragmatics: The case of requests. In Phillipson, R. R. et al. (Eds.) Foreign/second language pedagogy research. (pp. 255-272). Clevedon: Multilingual Matters Ltd.

Blum-Kulka, S., House, J., \& Kasper, G. (1989). Investigating Cross-cultural Pragmatics: An introductory overview. In Blum-Kulka, House \& Kasper (Eds). Cross-Cultural Pragmatics:Requests and Apologies. (pp. 1-34). New Jersey: Ablex Publishing Corporation.

Barron, A. (2003) Acquisition in interlanguage pragmatics: Learning how to do things with words in a study abroad context. Amsterdam: Benyamins. https://doi.org/10.1075/pbns.108

Chomsky, N. (1980). Rules and representations. New York: Columbia University Press.

Crystal, D. (1997). A dictionary of linguistics and phonetics. 4th edition. Cambridge, MA: Blackwell.

Crystal, D. (1997). A dictionary of linguistics and phonetics. 4th edition. Cambridge, MA: Blackwell.

Fraser, B. (1983). The domain of pragmatics, in J. C. Richard \& R. W. Schmidt (Eds.), Language and communication (p. 29-59). New York: Longman

Gharaghani, Z., Eslami Rasekh, A., Dabaghi, A., \& Tohidian, I. (2001). Effect of Gender on politeness strategies in greetings of native speakers of Persians; English and EFL Learners. Cypriot Journal of Educational Sciences, 3, 93-117

Morris, C. (1938). Foundations of the theory of signs. In Neuratin, O., Carnap, R., \& Morris, C. (Eds.) International encyclopedia of unified science, vol.2, bk 1. Chicago: University of Chicago Press.

Morris, C. (1938). Foundations of the theory of signs. In Neuratin, O., Carnap, R., \& Morris, C. (Eds.) International encyclopedia of unified science, vol.2, bk 1. Chicago: University of Chicago Press.

Rafieyan, V. (2016a). Effect of cultural distance on pragmatic comprehension and production. Advances in Language and literary studies, 7(4), 25-32

Rafieyan, V. (2016b). Effect of pragmatic instruction versus educational sojourn on knowledge of conventional expression. International Journal of learning and development, 6(2), 1-12. https://doi.org/10.5296/ijld.v6i2.9403

Rafieyan, V. (2016c). Bridging pragmatic gap in translation process through developing pragmatic awareness. Journal for the study of English Linguistics, 4(1), 98-110. https://doi.org/10.6296/jsel.v4il.9667 